\section{Flavoured, non-cigarette tobacco for sale in the USA: an inventory analysis of Internet retailers}

Tobacco companies flavour their products in order to recruit new, younger users. ${ }^{1}$ Flavours like menthol, cherry, grape and chocolate mask the harshness of tobacco, making it easier to become addicted. ${ }^{2}$ These flavours also appeal to young tobacco users. In Maryland, about four in five underage cigar smokers smoke flavoured cigars. ${ }^{3}$ Nationally, $57 \%$ of young adult (ages 1824) cigar smokers smoke flavoured cigars. ${ }^{4}$ Since 2009, menthol and tobacco are the only flavours allowed in cigarettes. ${ }^{5}$ As of March 2013 the federal government does not restrict flavours in tobacco products other than cigarettes, though federal courts recently upheld flavoured tobacco sales bans enacted in New York City and Providence, Rhode Island. ${ }^{6}$

To inform tobacco control efforts, we conducted this study of Internet tobacco retailers to describe the variety and flavours of tobacco products for sale in the USA. We identified a convenience sample of 18 Internet tobacco retailers, selected from the top search results for various kinds of tobacco products (eg, moist snuff, cigars). Data on dissolvable tobacco came from a list maintained by the Oregon Department

Table 1 Study sample of 8426 tobacco products for sale online in the USA

\begin{tabular}{|c|c|c|c|c|c|c|c|c|c|}
\hline & $\begin{array}{l}\text { Brands } \\
\mathrm{N}\end{array}$ & $\begin{array}{l}\text { Products } \\
\mathrm{N}\end{array}$ & $\begin{array}{l}\text { Any flavour } \\
\%\end{array}$ & $\begin{array}{l}\text { Fruit } \\
\%\end{array}$ & $\begin{array}{l}\text { Sweet } \\
\%\end{array}$ & $\begin{array}{l}\text { Mint } \\
\%\end{array}$ & $\begin{array}{l}\text { Liquor } \\
\%\end{array}$ & $\begin{array}{l}\text { Menthol } \\
\%\end{array}$ & $\begin{array}{l}\text { Other } \\
\%\end{array}$ \\
\hline Total & 849 & 8426 & 22.5 & 11.9 & 5.2 & 2.9 & 2.3 & 1.6 & 3.3 \\
\hline Chewing tobacco & 71 & 163 & 35.0 & 17.2 & 17.2 & 3.7 & 3.1 & 0.6 & 4.3 \\
\hline Cigars & 513 & 5385 & 9.5 & 4.5 & 4.0 & 0.3 & 1.0 & 1.3 & 1.0 \\
\hline Hand-rolled premium cigars & 398 & 4628 & 3.3 & 0.8 & 1.3 & 0.2 & 0.5 & 0.1 & 0.7 \\
\hline Cigarette-sized cigars & 64 & 325 & 52.3 & 31.4 & 19.7 & 0.9 & 3.1 & 18.5 & 4.9 \\
\hline Machine-made large cigars & 61 & 432 & 43.8 & 23.8 & 20.1 & 0.5 & 3.9 & 1.4 & 1.6 \\
\hline Cigar wraps & 6 & 91 & 81.3 & 63.7 & 8.8 & 0.0 & 11.0 & 0.0 & 4.4 \\
\hline Dissolvables & 3 & 11 & 81.8 & 9.1 & 0.0 & 45.5 & 0.0 & 0.0 & 27.3 \\
\hline Dry snuff & 58 & 577 & 44.4 & 16.1 & 8.5 & 6.8 & 4.3 & 5.4 & 13.0 \\
\hline Moist snuff & 32 & 187 & 55.1 & 8.6 & 1.6 & 43.3 & 0.5 & 0.0 & 1.6 \\
\hline Pipe tobacco & 167 & 1865 & 45.7 & 29.9 & 7.3 & 4.1 & 5.5 & 1.3 & 7.0 \\
\hline Traditional pipe tobacco & 99 & 912 & 17.2 & 5.9 & 7.3 & 0.1 & 4.9 & 0.3 & 4.2 \\
\hline Dual purpose pipe tobacco & 41 & 174 & 14.4 & 2.9 & 2.9 & 7.5 & 1.1 & 12.6 & 0.6 \\
\hline Shisha & 28 & 779 & 86.1 & 63.9 & 8.2 & 8.1 & 7.2 & 0.0 & 11.7 \\
\hline Roll-your-own cigarette tobacco & 16 & 66 & 15.2 & 13.6 & 1.5 & 0.0 & 0.0 & 13.6 & 0.0 \\
\hline Snus & 30 & 81 & 33.3 & 3.7 & 1.2 & 27.2 & 1.2 & 0.0 & 0.0 \\
\hline
\end{tabular}


of Justice, ${ }^{8}$ as these products could not be found for sale online.

We identified every tobacco product from each data source and classified products by type and flavour. 'Mint' included products with descriptors such as cool, fresh, ice, peppermint, spearmint and wintergreen. 'Fruit' included apple, apricot, cherry, grape and strawberry. 'Liquor' included margarita, rum, whisky and wine. 'Sweet' included bubble gum, candy, chocolate, honey, toffee and vanilla. 'Other' flavours include coffee, hickory and spice. Flavours like 'honey berry' were classified as both Fruit and Sweet. Both authors coded data, and resolved discrepancies by consensus. After removing duplicates, the final sample was 8426 unique non-cigarette tobacco products.

Of the tobacco products identified for this study, 1900 (23\%) were flavoured (table 1). Apple, cherry, chocolate, honey, grape, menthol, mint, peach, rum, strawberry, sweet and vanilla were the most common flavours. Shisha (hookah tobacco) had the greatest number of flavours. Flavours were identified in over $80 \%$ of shisha, dissolvable tobacco and cigars wraps. Over $40 \%$ of the cigarettesized cigars, machine-made cigars, moist snuff and dry snuff products identified were flavoured. Flavours were least common among hand-rolled premium cigars (3\%). About one out of seven loose cigarette tobacco products were flavoured, whether sold as roll-your-own cigarette tobacco or 'dual purpose pipe tobacco', a designation that is used to avoid taxes. ${ }^{9}$

We found a large number of flavoured tobacco products for sale on the Internet. The convenience sample of Internet retailers limits generalisability but does not negate the finding that many flavoured tobacco products are available for online purchase. Though we identified many products others are surely missing from the study sample. If a full list of tobacco products for sale was available from the Food and Drug Administration, this study could be replicated with more robust results. Applying the cigarette flavour ban to other tobacco products might reduce sales of these products and discourage youth initiation. Few hand-rolled premium cigars would be affected by a flavour ban.

\section{What this paper adds}

- This is the first study of Internet tobacco retailers to describe the variety and flavours of non-cigarette tobacco products for sale in the USA.

- Out of 8426 non-cigarette tobacco products identified, 1900 (23\%) were flavoured; flavours were most common in hookah tobacco, dissolvables and cigar wraps. Flavours were least common among hand-rolled premium cigars.

- Applying the cigarette flavour ban to non-cigarette tobacco products might reduce sales of these products and discourage youth initiation. A flavour ban would have little effect on the premium cigar market.

\section{Daniel S Morris, Steven C Fiala}

Portland, Oregon, USA

Correspondence to Dr Daniel S Morris, 813 SW Alder St., Suite 800a, Portland, OR 97205, USA; danielmorrisphd@gmail.com

Acknowledgements We thank David Hopkins for his critical review of the manuscript.

Contributors DSM designed the study, collected data, and conducted data analysis; SCF assisted with data collection and management, and contributed to writing and editing of the manuscript.

Funding This article was written as part of a grant-funded research project. Any public dissemination of information relating to the grant was made possible by Grant Number RC-2009-0035 from ClearWay
Minnesota ${ }^{\mathrm{SM}}$. The contents of this information are solely the responsibility of the authors and do not necessarily represent the official views of ClearWay Minnesota.

Competing interests None.

Provenance and peer review Not commissioned; externally peer reviewed.

Data sharing statement The authors will share data used in this study upon request.

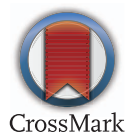

To cite Morris DS, Fiala SC. Tob Control 2015:24:101-102.

Accepted 23 July 2013

Published Online First 8 August 2013

Tob Control 2015;24:101-102.

doi:10.1136/tobaccocontrol-2013-051059

\section{REFERENCES}

1 Freedman AM. Juiced up: how a tobacco giant doctors snuff brands to boost their 'kick'. U.S. Tobacco raises the $\mathrm{PH}$, increasing the nicotine a user's mouth absorbs. Cherry Skoal for beginners. The Wall Street Journal. October 26, 1994.

2 WHO Study Group. The scientific basis of tobacco product regulation. World Health Organ Tech Rep Ser 2007;945:1-112.

3 Maryland Department of Health and Mental Hygiene. Disturbing facts: single sale and flavored cigars. Published 26 January 2012. http://dhmh.maryland.gov/thecigartrap/ new/DisturbingFacts_1.pdf (accessed 12 Nov 2012).

4 King BA, Dube SR, Tynan MA. Flavored cigar smoking among U.S. adults: findings from the 2009-2010 National Adult Tobacco Survey. Nicotine Tob Res 2013;15:608-14.

5 Family Smoking Prevention and Tobacco Control Act, Pub. L. No. 111-31, 123 Stat. 1776 (22 June 2009).

6 U.S. Smokeless Tobacco Mfg. Co., et al. v. City of New York, 11-5167-cv (U.S. Court of Appeals for the 2nd Circuit. 2013).

7 Nat'I Ass'n of Tobacco Outlets, Inc. v. City of Providence, 12-96-ML (U.S. District Court for the District of Rhode Island, 2012).

8 Oregon Department of Justice. Smokeless Tobacco Directory. http://www. doj.state.or.us/tobacco/pdf/ smokeless_tobacco_directory.pdf (accessed 4 Oct 2011).

9 United States Government Accountability Office. Tobacco taxes: large disparities in rates for smoking products trigger significant market shift to avoid higher taxes. Published April 2012. http://www.gao. gov/assets/600/590192.pdf (accessed 6 Nov 2012). 